\author{
Maksym Baranovskyi ${ }^{1}$
}

\title{
THREATS AND CHALLENGES IN THE FISCAL SPHERE OF UKRAINE AND WAYS TO OVERCOME THEM
}

Keywords: fiscal sphere, fiscal policy, threats and challenges in the fiscal sphere, fiscal security, fiscal sphere capacity.

ABSTRACT: The article considers the main threats and challenges to the stable and effective development of the fiscal sphere in Ukraine and the reasons for their occurrence. The ways to overcome these problems are identified.

It was noted that the development of the fiscal system in Ukraine since the independence has been accompanied by complex transformations associated with the corresponding steps in its organizational restructuring with changes in legal entities. Accordingly, since independence, the development of the fiscal sphere has undergone 6 stages, that affected the overall state of its development.

It was shown that such a complex way of evolution of the fiscal service in Ukraine has left its mark on the complicating circumstances that accompanied its development, which is manifested in the still insurmountable challenges and impending threats that hinder the stable and effective development of this important institution in the system of public administration.

The article identifies the challenges and threats that accompany the development of the fiscal sphere in modern Ukraine: the dogmatic nature of fiscal policy, its separation from the actual state of affairs in the economy; low economic development caused by its shadowing and high inflation, etc.

The goal of the article is to identify threats and challenges in the implementation of effective domestic fiscal policy and to disclosure strategic ways of the fiscal sphere development in Ukraine for overcoming threats and challenges.

1 Postgraduate Student at the Department of Parliamentarism and Political Management, National Academy for Public Administration under The President of Ukraine, maksim.vladimirovih@ukr.net. ORCID: 0000-0002-3107-0509. 
It was demonstrated that in order to increase the level of efficient functioning of the fiscal sphere and ensure the fiscal security of Ukraine, first of all, a political will and a system of measures that prevent and counteract its threats and challenges are needed.

Another important step towards increasing the capacity of the fiscal sphere is the adoption of a number of management decisions in the system of public administration regarding the fiscal sphere functioning. It is also necessary to carry out reforms in the law enforcement sphere, modernize law enforcement practices as well as to conduct the necessary intelligence activities for studying the current situation in its development, where threats are relevant.

\section{INTRODUCTION}

The development of modern Ukraine and the achievement of its high indicators directly depend on the formation of a coherent and effective financial policy, including fiscal one. However, there is no sufficient stability in this area nowadays, which, accordingly, has a negative impact on the quality of economic development of the state. The major difficulty in achieving positive results on the way to economic stability and high performance of the state is the overcoming of the challenges and threats in the fiscal area. This requires purposeful work of public authorities on reforming and improving the basic principles of fiscal policy and their implementation.

The difficulties in ensuring an effective fiscal policy today are related to the challenges and problems facing Ukraine. First of all, it is the RussianUkrainian war in the East of the country, which leads, among other things, to a significant burden on the economic sphere due to the great damage to the economic infrastructure in the country. The external economic challenges, internal disorganization of the economic situation, and the slow pace of necessary institutional and structural reforms also have a negative impact on the development of the fiscal sphere. All this has an impact on the fiscal sphere and leads to serious difficulties in ensuring its sustainable development.

In connection with the mentioned above, there is a question of studying threats and challenges in the fiscal sphere at the national and scientific levels in order to develop a strategy for effective steps in improvement of 
fiscal policy as an important component of solving major problems in the public administration.

Analysis of recent researches and publications. The article addresses the scientific research of such Ukrainian scientists as O. Desyatnyuk, O. Slastyonenko, T. Kozachyshyn, V. Nekrasov, O. Korystin, whose research raised the problems of the fiscal sphere, the existing challenges and threats in its development, as well as strategic development of the fiscal sphere in order to prevent and overcome these problems.

They also referred to the relevant regulations, which regulate the peculiarities of the fiscal sphere development and identify strategic directions of its improvement in the state, taking into account the problems associated with the challenges and threats.

The current publication is an add-on in scientific researches, which were conducted independently and the results of which were demonstrated in the author's scientific articles and conference proceedings (Baranovskyi, 2019; 2020).

The goal of the article is to identify threats and challenges in the implementation of effective domestic fiscal policy and reveal strategic ways of the fiscal sphere development in Ukraine in order to overcome defined threats and challenges.

The research objectives of the scientific article are to identify the main threats and challenges to the stable and effective development of the fiscal sphere in Ukraine and the reasons for their occurrence. It is also important to reveal the principles of preventing and overcoming threats and challenges, including through the provision of law enforcement activities that will be able to prevent and counteract illegal actions of officials in the fiscal sphere.

The study of problems and threats in the fiscal sphere conducted in the current scientific article was based on the following methods of scientific research: historical, comparative and systematic analysis. 


\section{FORMATION AND DEVELOPMENT OF THE FISCAL SPHERE IN UKRAINE}

The fiscal sphere in modern Ukraine is represented by following institutions: the State Tax Service of Ukraine, the State Customs Service of Ukraine and the State Fiscal Service of Ukraine. They were finally created in 2018 in the process of organizational restructuring that took place since Ukraine's independence.

To date, some difficulties in achieving the effective implementation of fiscal policy in Ukraine are due to the fact that since independence, the fiscal service system in Ukraine has undergone significant reforms and related transformations for decades.

In general, there are several stages in the development of the fiscal service system since the independence of Ukraine:

1) (1990-1996 pp.) - creation of the State Tax Inspectorate of Ukraine within the Ministry of Finance;

2) (1996-2000 pp.) - formation of the State Tax Administration as an independent body of executive power, changing the level of subordination of the tax service;

3) (2000-2011 pp.) - modernization and reorganization of tax service in the framework of implementing the state policy of European integration of Ukraine;

4) (2012-2014 pp.) - creation of the Ministry of Revenue and Duties by merging the Tax Service and Customs Service.

5) (end of 2014 - end of 2018) - creation of the State Fiscal Service of Ukraine;

6) (from the end of 2018) - creation of the State Tax Service of Ukraine and the State Customs Service of Ukraine as central executive bodies to ensure the implementation of state policy in the tax and customs spheres respectively (Baranovskyi, 2019, p. 25).

The final step in reforming the organizational structure of the fiscal sphere was the adoption of the Resolution of the Cabinet of Ministers № 1200 "On the establishment of the State Tax Service of Ukraine and the State Customs Service of Ukraine" (December 18, 2018). According to this document, the State Tax Service of Ukraine and the State Customs Service 
of Ukraine became the central executive bodies for ensuring the implementation of state policy in the tax and customs spheres (Resolution of the Cabinet of Ministers of Ukraine, 2018).

Accordingly, such a complex nature of the evolution of the fiscal service in Ukraine due to the constant restructuring of its bodies has left its mark on the complicating circumstances that accompanied its development. Today, this is demontrated in the still insurmountable challenges and impending threats that hinder the stable and effective development of this important institution in the system of public administration.

\section{THREATS AND CHALLENGES IN THE FISCAL SPHERE IN UKRAINE}

One of the most difficult problems in ensuring the sustainable development of the state is the conduct of ineffective fiscal policy and the presence of significant threats and challenges in the fiscal sphere.

According to O. Desyatniuk, the difficulties that affect the inefficiency of fiscal policy implementation and, accordingly, pose a serious threat to the macroeconomic stability of Ukraine are related to the following factors: increasing the fiscal pressure on the economy; deformation of the structure of the revenue side of the state budget; reducing the efficiency of public investment as a factor of economic recovery; growing deficit of the budget. Also, the important factors in the occurence of fiscal policy risks, which have a high probability of being affected by such macroeconomic risks, are: risks of technical default; risks of excessive government activity in the domestic debt market that leads to the displacement of private investment due to increased government borrowing; maintaining the validity and stability of the taxation level; maintaining sufficient fiscal flexibility to enable effective demand management; maintaining sustainable levels of the state deficit and debt (Desyatnyuk).

According to Slastyonenko OO, the urgent problems in the development of modern fiscal policy include its dogmatic nature, as well as its inability to respond quickly to the conditions of our economy, poorly justified tactical measures aimed at short-term benefits; separation of 
fiscal policy from the actual state of affairs in the economy; breach of the balance of the state budget of Ukraine; residual approach in determining the financial base to meet the social needs of citizens (Slastyonenko, Pershko, 2016).

Among the complicating circumstances of the fiscal sphere development, it is also necessary to note the problem that accompanies the economic development of the state. We are talking about a high level of inflation and shadowing of the economy in Ukraine.

Also, the following threats in the field of fiscal security of Ukraine are highlighted: VAT fraud; "schemes" to minimize tax payments; lobbying by government officials of certain groups and companies to promote favorable tax (customs) conditions (preferences) for them; shadowing of certain businesses; information attacks on discrediting the fiscal system; manifestations of corruption in the fiscal sphere (Presentation, 2020).

The extreme damage to ensuring the effective operation of the fiscal system is the pressure on business in Ukraine. Such illegal actions are reduced to the so-called proposals to pay taxes to entrepreneurs in advance, unjustified submission of materials to the Uniform Register of Pre-Trial Investigations (URPI), the establishment of operational and investigative cases, etc.

An important component in determining the risks in the development of the fiscal sphere is the probability of threats and their consequences.

In connection with the above, the purposes of modern state fiscal policy are: identifying the threats in the fiscal sphere; their rating and ranking; assessing the vulnerability of society to counter identified threats; creating a model and forecast of risk management, as well as determining the ability of fiscal actors to resist various threats, assessment of key factors in the development of the fiscal sphere and ensuring its effective development.

These problems in the development of the fiscal sphere are extremely worrying for both government officials, fiscal specialists and scientists, as well as the whole civil society.

A valuable scientific study on these issues was the research, the results of which were presented at the meeting on December 22, 2020 in the relevant scientific and professional environment, which included, in particular, Grigola Katamadze (Ambassador Extraordinary and Plenipotenti- 
ary, President of the Taxpayers' Association of Ukraine, Vice President of the European Association of Taxpayers, Member of the Supervisory Board of the Ukrainian Business Council, Member of the Board of the State Tax Service of Ukraine); Vyacheslav Nekrasov (Advisor of the Chairman of the State Fiscal Service of Ukraine, Assistant Consultant of the People's Deputy of Ukraine, Advisor to the President of the the Taxpayers' Association of Ukraine, Associate Professor); Oleksandr Korystin (Chief Research Fellow of the State Research Institute of the Ministry of Internal Affairs of Ukraine, Professor, Honored Worker of Science and Technology of Ukraine). The results of the strategic analysis on the assessment of risks and threats to fiscal security of Ukraine carried out at the initiative of the Association of Taxpayers of Ukraine were presented at that meeting (Presentation, 2020).

This strategic analysis was carried out in the form of a survey. This survey was conducted in the expert community of representatives of the State Tax Service of Ukraine, the State Customs Service of Ukraine, the State Fiscal Service of Ukraine and the business environment.

The main purpose of the study was a strategic analysis of fiscal security. The main objectives of the research were: to identify, rank and range threats to fiscal security (probability and consequences); to assess threats to fiscal security; to analyse and assess risks of the spread of fiscal security threats; to assess the capacity / vulnerability of the fiscal system ragarding minimization the level of risks of the spread of fiscal security threats; to assess external opportunities related to possible increase of fiscal security level; to model and forecast risks (Presentation, 2020).

According to the results of research conducted through surveys in the professional environment, 243 existing threats in the field of fiscal security were identified. In particular, the following main threats in the fiscal sphere were identified: VAT fraud, "schemes" to minimize tax payments, lobbying by government officials of certain groups and companies to promote favorable tax (customs) conditions (preferences); shadowing of certain businesses; information attacks aimed to discredit fiscal system; manifestations of corruption in the fiscal sphere.

It was determined that 144 of 243 threats in the fiscal service are related to the State Tax Service. 
According to the research, taking into account the limit values of probability and consequences, all risks in the State Tax Service are quantitatively divided into four groups:

- Group 1 - the most significant (red) - 9 risks, require urgent measures to reduce the risk of their spread;

- Group 2 - significant (orange) - 54 risks, need the control of top management;

- Group 3-72 risks, need attention, but not paramount;

Group 4-9 risks, need to be tracked (Presentation, 2020)

Accordingly, the group of significantly high risk in the State Tax Service includes: VAT fraud, "schemes" to minimize tax payments and lobbying for certain interests in the fiscal sphere. A high risk in this area is the shadowing of certain types of business and manifestations of corruption in the fiscal sphere. Less risky for fiscal security are information attacks to discredit the fiscal system (Presentation, 2020).

One of the biggest threats in the State Fiscal Service is the avoidance of criminal prosecution for tax offenses. The main reasons for such threats in Ukraine are the imperfection of the Criminal Code of Ukraine regulations; gaps in the Criminal Procedure Code of Ukraine; imperfection of tax legislation; imperfection of customs legislation; inefficiency of the organization of pre-trial investigation as well as inefficiency of operativesearch and prosecutor's office activities; carrying out consideration of materials of criminal proceedings in courts; counteraction to criminal prosecution (Presentation, 2020).

The biggest threats to the functioning of the State Customs Service are smuggling, underestimation of customs value and violations of customs regulations.

The major threats to the stable development of the state, and accordingly to the effective operation of the fiscal service are threats of a macroeconomic nature. This is the essence of the external conditions of fiscal security

The most significant threats here are: shadow economic activity, which negatively affects fiscal security; monopolization of markets and industries; decline in production in the country; reduction of the official labor market; labor migration; outflow of labor abroad. 
It should be noted that the fiscal sphere is also extremely sensitive to the spread of corruption. As it is noted by L. Dubchak, the causes of this phenomenon have both individual and social nature, in particular: economic factors; instability of social development; short-term planning in public policy and others. Therefore, it is absolutely not obvious that corruption spreads only among a certain social stratum and, as is commonly believed, among the highest levels of the management sector (Dubchak, 4, p. 67). Accordingly, the fiscal sphere is quite seriously exposed to the threat of corruption.

Among the significant problems that pose a threat to the effective functioning of the fiscal service in Ukraine are: the activities of "conversion centers"; raiding; legalization of shadow income; wages "in envelopes"; kickbacks in business transactions; unavailability of cheap bank loans and replacement by alternative (shadow) resources (Presentation, 2020).

Thus, the complexity of the fiscal sphere tasks is related to a wide range of threats and challenges that loom over it, reduce the effectiveness of fiscal policy and affect fiscal security.

\section{WAYS TO OVERCOME THREATS AND RISKS IN THE DEVELOPMENT OF THE FISCAL SPHERE OF UKRAINE}

In order to increase the level of efficient functioning of the fiscal sphere and ensure the fiscal security of Ukraine, first of all, political will and a system of measures to prevent and counter to threats and challenges are needed.

Due to the above important steps towards increasing the capacity of the fiscal sphere, it is necessary to make a number of management decisions in the system of public administration regarding to its functioning. The current tasks in developing a general strategy for reforming the fiscal service should be based on setting national priorities, creating perfect principles of targeted budgeting and creating appropriate conditions to ensure the effective operation of relevant fiscal authorities and the use of budget funds (Presentation, 2020). 
A special place on this path is the implementation of reforms in the law enforcement sphere. According to the study, the following steps are required:

- creation of a single law enforcement agency in the field of finance and economic crimes;

- deprivation of authority of National Police of Ukraine to investigate criminal offenses of an economic nature;

- deprivation of authority of the Security Service of Ukraine to investigate criminal offenses of an economic nature, etc. (Presentation, 2020).

Thus, according to V. Nekrasov, in order to solve problems in overcoming threats in the fiscal sphere, a system of institutions is needed, where law enforcement agencies should take a special place. This will provide an opportunity: to create appropriate strategic management; to assess risks accurately; to identify threats, as well as to create mechanisms to overcome relevant threats and risks (Presentation, 2020).

Along with the important strategic task of creating an appropriate law enforcement agency that will prevent and combat threats in the fiscal sphere, it is also important to modernize the law enforcement practice itself, which will underlie the activities of this law enforcement agency.

In law enforcement practice, it is important to update, innovate, and optimize measures to combat crime, in particular, in the fiscal sphere. It is necessary to use information and telecommunication technologies and apply new methods of analytical work not only as a tool for gathering evidence, but also as a resource for strategic planning, which provides vital directions for the deployment of strategies and resources to ensure their implementation.

The intelligence should also play an important role in overcoming risks and challenges in the fiscal sphere, which should be aimed at studying the current situation in its development, where threats are relevant. 


\section{CONCLUSIONS}

Thus, the fiscal sphere in modern Ukraine is experiencing difficulties associated with both external challenges and internal features of the formation and implementation of domestic fiscal policy. The significant problems in development of the fiscal policy are also related to the complex organizational transformations that the fiscal sphere has undergone since Ukraine's independence (the evolution of Ukraine's fiscal sphere since 1991 took place in six stages).

The attention was drawn to the fact that such a complex path of evolution of the fiscal sphere in Ukraine has left its mark on the difficult circumstances that accompanied its development. It is manifested in insurmountable challenges and impending threats that hinder the stable and effective development of this important institution in the system of public administration.

As a conclusion, in order to increase the level of efficient functioning of the fiscal sphere and ensure the fiscal security of Ukraine, first of all, political will and a system of measures to prevent and counter its threats and challenges are needed. Also, the important step towards increasing the capacity of the fiscal sphere is making a number of necessary management decisions in the public administration system regarding its functioning. This should include law enforcement reforms, modernization of law enforcement practice and conducting necessary intelligence activities to study the current situation in its development, where threats are actualized.

The prospects for further research can be scientific-theoretical and applied research and developments, the content of which will allow to analyze the features of the fiscal sphere in Ukraine in more detail and broadly as well as identify ways to overcome threats and challenges that will bring their functioning to a more efficient level. 


\section{BIBLIOGRAPHY:}

Baranovskyi, M.V. (2019). Evoliutsiia instytutiv fiskalnoi sluzhby Ukrainy [Evolution of institutes of the Fiscal Service of Ukraine]. Public administration in Ukraine, vol. 14,pp. 23-28. Retrieved from: http://www.pag-journal.iei.od.ua/archives/2019/14-2019/6.pdf

Baranovskyi, M.V. (2020). Formuvannia novitnikh orhanizatsiino-pravovykh mekhanizmiv funktsionuvannia instytutiv fiskalnoi sluzhby [Formation of the newest organizational and legal mechanisms of functioning of institutes of the Fiscal Service]. Law and public administration, pp. 166-171. Retrieved from: http://pdu-journal. kpu.zp.ua/archive/4_2020/15.pdf.

Desiatniuk, O. (2012). Ryzyky fiskalnoi polityky yak zahroza makroekonomichnii stabilnosti derzhavy [Risks of fiscal policy as a threat to macroeconomic stability of the state]. World of Finance, no. 4, pp. 23-32. Retrieved from: http://dspace.wunu.edu.ua/ bitstream/316497/18550/1/\%D0\%94\%D0\%B5\%D1\%81\%D1\%8F\%D1\%82\%D0\%B D\%D1\%8E\%D0\%BA\%20\%D0\%9E..pdf.

Dubchak, L.M. (2017). Stratehii formuvannia derzhavnoi polityky borotby z koruptsiieiu $\mathrm{v}$ sviti [Strategies for establishing the state policy to combat corruption in the world]. Proceedings of the Days of Science of the Faculty of Philosophy (Ukraine, Kyiv, April 25-26, 2017). (eds. Konverskyi A.Ye.), Kyiv: Kyivskyi universytet, no. 8, pp. 67-70.

Kozachyshyna, T.O. (2018). Suchasni vyklyky ta zahrozy formuvannia y realizatsii biudzhetno-podatkovoi polityky v Ukraini [Current challenges and threats to the formation and implementation of the fiscal policy in Ukraine]. Scientific notes of TNU. VI Vernadsky. Series: Public Administration, vol. 29 (68), no. 5, pp. 26-33. Retrieved from: http://www.pubadm.vernadskyjournals.in.ua/journals/2018/5_2018/7.pdf.

Prezentatsiia (2020). Prezentatsiia rezultativ stratehichnoho analizu shchodo otsinky ryzykiv ta zahroz fiskalnoi bezpeky Ukrainy [Presentation of the results of the strategic analysis on the assessment of risks and threats to the fiscal security of Ukraine]. 22.12.2020. Retrieved from: https://appu.org.ua/main-news/prezentacziya-rezultativstrategichnogo-analizu-shhodo-oczinki-rizikiv-ta-zagroz-fiskalno\%D1\%97-bezpekiukra\%D1\%97ni-2/.

Postanova KMU (2018). Pro utvorennia Derzhavnoi podatkovoi sluzhby Ukrainy ta Derzhavnoi mytnoi sluzhby Ukrainy [On the establishment of the State Tax Service of Ukraine and the State Customs Service of Ukraine]. Postanova KMU vid 18 hrudnia 2018. № 1200. Retrieved from: https://zakon.rada.gov.ua/laws/show/1200-2018\%D0\%BF\#Text. [in Ukrainian].

Slastonenko, O.O., Pershko, O.O. (2016). Meinstrim fiskalnoi polityky v Ukraini [Mainstream of the fiscal policy in Ukraine]. Proceedings of the Transformation of Ukraine's fiscal policy in the context of European integration (Ukraine, Irpin, 1-15 December, 2016). Retrieved from: http://ndi-fp.nusta.com.ua/thesis/315/. 